Article

\title{
Reduction in Nitrogen Exports from Stormflow after Conversion of a Dry Detention Basin to a Stormwater Wetland
}

\author{
Charles P. Humphrey, Jr. * and Guy Iverson \\ Environmental Health Science Program, Department of Health Education \& Promotion, East Carolina University, \\ Greenville, NC 27834, USA; Iversong18@ecu.edu \\ * Correspondence: Humphreyc@ecu.edu
}

Received: 30 November 2020; Accepted: 16 December 2020; Published: 17 December 2020

\begin{abstract}
Stormwater control measures such as dry detention basins and wetlands are often used to reduce the discharge of urban runoff and nutrients to streams, but differences in nutrient treatment may vary between practices. The goal of this study was to compare the nitrogen treatment efficiency of a dry detention basin before and after it was converted into a stormwater wetland. Inflow and outflow from a detention basin in Greenville, North Carolina was sampled during 13 storms and the stormwater wetland was sampled during 10 storms. Total dissolved nitrogen (TDN), $\mathrm{NO}_{3}{ }^{-}$, $\mathrm{NH}_{4}{ }^{+}$, chloride, dissolved organic carbon (DOC), and physicochemical properties were evaluated. Inflow and outflow from the detention basin had identical median concentrations of $\operatorname{TDN}\left(0.47 \mathrm{mg} \mathrm{L}^{-1}\right)$. The median TDN concentration for wetland outflow $\left(0.18 \mathrm{mg} \mathrm{L}^{-1}\right)$ was $63 \%$ lower relative to inflow $\left(0.49 \mathrm{mg} \mathrm{L}^{-1}\right)$. The hydraulic residence time of stormwater in the wetland was more than 10 times greater relative to the dry basin. There was a significant $(p<0.001)$ reduction in dissolved oxygen and oxidation reduction potential and an increase in median DOC concentrations in wetland outflow relative to inflow. Most of the reduction in TDN within the wetland was attributed to loss of $\mathrm{NO}_{3}{ }^{-}$ ( $80 \%$ reduction), possibly due to denitrification. Conversion of dry detention basins to wetlands may provide significant benefits with regards to reducing TDN transport associated with urban runoff.
\end{abstract}

Keywords: dry detention basin; nitrogen; stormwater; urban runoff; wetlands

\section{Introduction}

Urban runoff is one of the most common causes of surface water impairment [1]. Hard and impervious surfaces, including asphalt parking lots, roads, buildings, and houses cover soil and thus reduce infiltration capacity leading to more runoff during rain events [2]. As the global population increases, so too will the coverage of impervious surface [3]. Runoff can cause flooding to downstream properties and transport various contaminants that accumulate on surfaces between storms, including animal waste and fertilizers, which are enriched with nitrogen [4-6]. Excess nitrogen loading has resulted in overstimulation of algal growth, eutrophication and impairment of surface waters in many regions around the world [7]. Various stormwater control measures (SCMs) have been implemented in urban areas to retain and/or to treat runoff near the source [8,9]. Dry detention basins were one of the first control measures widely used in many countries and most were designed with a main goal to reduce the peak rate of runoff $[4,10,11]$. Dry basins allow infiltration of runoff and slow the release of stormwater through an outlet structure. Dry detention basins are relatively easy to construct, require low maintenance, and may also provide for recreational activities during dry periods [10]. However, studies have shown that the nitrogen treatment efficiency of dry basins is poor, highly variable, and some basins may actually export nitrogen [8]. For example, in a literature 
review [8] that included influent and effluent data from 25 dry ponds, the mean and median nitrogen concentrations in dry pond effluent were more than $75 \%$ greater relative to influent concentrations. The dry ponds in those studies were sources of nitrogen. The authors [8] also reviewed data from 9 other dry ponds and reported median nitrogen load removals of $25 \%$. The authors cited factors including detention time and density of vegetation as factors that influenced the treatment efficiency of the dry basins. Based on the data in the review [8], the expected median nitrogen removal rates of dry ponds may range from $-75 \%$ to $25 \%$.

Constructed stormwater wetlands are another SCM used to reduce the peak rate of runoff and for nutrient treatment. Components of a stormwater wetland typically include a forebay to dissipate the energy of influent, shallow water channel that directs flow towards the outlet, shallow land that is vegetated with wetlands plants, and an outlet structure [12]. Wetlands are typically more expensive to design and install, and require more land area, but may provide better nutrient removal relative to dry basins [12]. In a review [8] of the total nitrogen (TN) treatment performance of 19 stormwater wetlands, mean and median effluent concentrations of TN were $43 \%$ and $48 \%$ lower respectively, relative to influent concentrations. Wetlands in those studies were sinks for nitrogen. Wetlands typically have a higher diversity and density of vegetation than dry basins. The wetland vegetation facilitate nitrogen removal via plant uptake and increase of soil organic carbon, which may fuel denitrification in anaerobic environments [8,11,12]. However, in highly aerated wetlands, mineralization of soil organic nitrogen and/or nitrification of ammonium $\left(\mathrm{NH}_{4}{ }^{+}\right)$may cause net exports of nitrogen [8]. While most stormwater wetlands have shown great capacity to reduce nitrogen transport, others were sources of nitrogen. More research is needed to quantify the nitrogen treatment efficiency of common SCM, including dry basins and wetlands, especially in nutrient-sensitive watersheds.

The effectiveness of SCMs in reducing nitrogen transport depends on the biochemical processes that are active within the sites. There are several potential removal mechanisms for nitrogen in SCMs including immobilization, adsorption, and denitrification $[8,13,14]$. Immobilization is the uptake of $\mathrm{NH}_{4}{ }^{+}$and/or nitrate $\left(\mathrm{NO}_{3}{ }^{-}\right)$by plants and/or microorganisms resulting in a transformation of inorganic to organic nitrogen. The transformation often does not result in a permanent loss of nitrogen mass unless the vegetation is harvested and removed from the wetland as a component of regular maintenance $[15,16]$. Without routine removal, plant debris may decompose and organic nitrogen may mineralize [13,17], contributing to nitrogen exports from the SCM. Adsorption is when $\mathrm{NH}_{4}{ }^{+}$is bound to the negative charges on soil particles via cation exchange. However, desorption and release may also occur [18] and thus $\mathrm{NH}_{4}{ }^{+}$removal via adsorption may only be temporary. The preferred method of nitrogen removal in an SCM is denitrification, the transformation of nitrate $\left(\mathrm{NO}_{3}{ }^{-}\right)$to $\mathrm{N}_{2}$ gas. Denitrification results in the loss of mass of nitrogen [17]. Denitrification requires anaerobic conditions, labile carbon, $\mathrm{NO}_{3}{ }^{-}$, and suitable environmental conditions (e.g., $\mathrm{pH}$, temperature) for denitrifying microorganisms $[2,8,19]$. In the absence of $\mathrm{O}_{2}$, denitrifying microorganisms can oxidize organic compounds and use $\mathrm{NO}_{3}{ }^{-}$as a terminal electron acceptor, thus reducing $\mathrm{NO}_{3}{ }^{-}$to $\mathrm{N}_{2}$ gas $[2,19]$. However, if oxygen is present in soil, then $\mathrm{O}_{2}$ will be utilized as the terminal electron acceptor during oxidation of organic compounds because it yields more energy [19]. Thus, denitrification may be inhibited if aerobic conditions are present. In some environments, denitrification rates may be limited based on the availability of carbon, which provides an energy (electron) source for microorganisms $[8,20]$. SCMs such as wetlands, which incorporate dense vegetation and have zones of stagnant water or water-logged soils, have the highest denitrification rate potential due to the build-up of soil organic matter and anaerobic conditions [14].

The speciation of influent nitrogen may influence the performance of an SCM in reducing nitrogen transport. A review of nitrogen speciation and concentrations in over 3700 stormwater samples from different land uses showed that $\mathrm{NO}_{3}{ }^{-}$accounted for $30 \%$ of total nitrogen concentration, while total Kjeldahl nitrogen (organic + ammonium) comprised 70\% [8]. Based on those numbers, the nitrogen removal efficiency via denitrification would not exceed 30\% unless a higher percentage of the total nitrogen entering the $\mathrm{SCM}$ was transformed to $\mathrm{NO}_{3}{ }^{-}$or the transformation occurred at the entrance of 
the control measure, and $\mathrm{NO}_{3}{ }^{-}$was exposed to denitrifying conditions prior to exiting. It is possible that organic nitrogen may mineralize to $\mathrm{NH}_{4}{ }^{+}$, a process called ammonification [20], and under oxic conditions ammonium $\left(\mathrm{NH}_{4}{ }^{+}\right)$can rapidly undergo nitrification [2]. These steps would enable subsequent denitrification if alternating oxic and anoxic conditions are found within the SCM along with other suitable environmental conditions. Microorganisms that facilitate nitrification are active when the $\mathrm{pH}$ is between 4.5 and 10, aerobic conditions are present, and the temperature is greater than $5^{\circ} \mathrm{C}$ [21]. Denitrifying microorganisms are active when the $\mathrm{pH}$ is above 5 , anoxic conditions are present, and the temperature is above $2{ }^{\circ} \mathrm{C}$ [21]. Nitrogen transformations may not occur if the environmental conditions within an SCM fall outside the range of conditions needed for microbial activity. Therefore, the nitrogen treatment efficiency of a SCM may be influenced by the speciation of influent nitrogen and environmental conditions within the practice that facilitate nitrogen transformations including nitrification and denitrification.

In North Carolina (NC), dry detention basins and constructed wetlands receive nitrogen reduction credits of $10 \%$ and $44 \%$ respectively, when installed to reduce stormwater runoff from new developments [22]. However, research has shown that the nitrogen treatment efficiency of dry basins and wetlands may be highly variable and more work is needed to better understand the factors which influence their performance [8]. Biogeochemical analyses of inflow and outflow from the basin and wetland were evaluated to determine if the conversion of a dry detention basin to a wetland resulted in lower exports of stormwater nitrogen.

\section{Materials and Methods}

\subsection{Site Description}

The study site is located at Jaycee Park in the City of Greenville, NC, USA (Figure 1). The park includes a playground, athletic field, skate park, a library, parking area, and a dry detention basin for stormwater management. The detention basin receives drainage from the park and approximately 10 ha of mixed residential and commercial real estate, resulting in $44 \%$ impervious surface for the watershed. The basin surface area was small ( $\sim .1 \mathrm{ha})$ relative to the watershed. The basin included a main inlet pipe ( $0.9 \mathrm{~m}$ diameter), a main outlet pipe ( $0.6 \mathrm{~m}$ diameter) on the basin bottom, and an overflow riser ( $\sim 1.5 \mathrm{~m}$ above grade) connected to a second outlet ( $0.6 \mathrm{~m}$ dimater) (Figure 2$)$. The basin was vegetated with volunteer trees, shrubs, and vines including Pinus taeda, Liquidambar styraciflua, Acer rubrum, Ligustrum sinense, and Toxicodendron radicans. Outflow from the basin discharges to Reedy Branch, a tributary of Greens Mill Run and the Tar River (Figure 1). Greens Mill Run and the Tar River are considered "impaired waters" and thus do not support all their designated uses such as aquatic habitat [23]. A watershed plan for Greens Mill Run was developed and eventually approved by the State of NC [24]. Sources of water use impairment were identified and suggested that remediation projects to improve water quality were listed in the plan. Conversion of the dry detention basin to a stormwater wetland at Jaycee Park was suggested. With funding made available from Sound Rivers via grants from the NC Department of Environmental Quality 319 Program and NC Clean Water Management Trust Fund, the dry detention basin was converted to a stormwater wetland. 


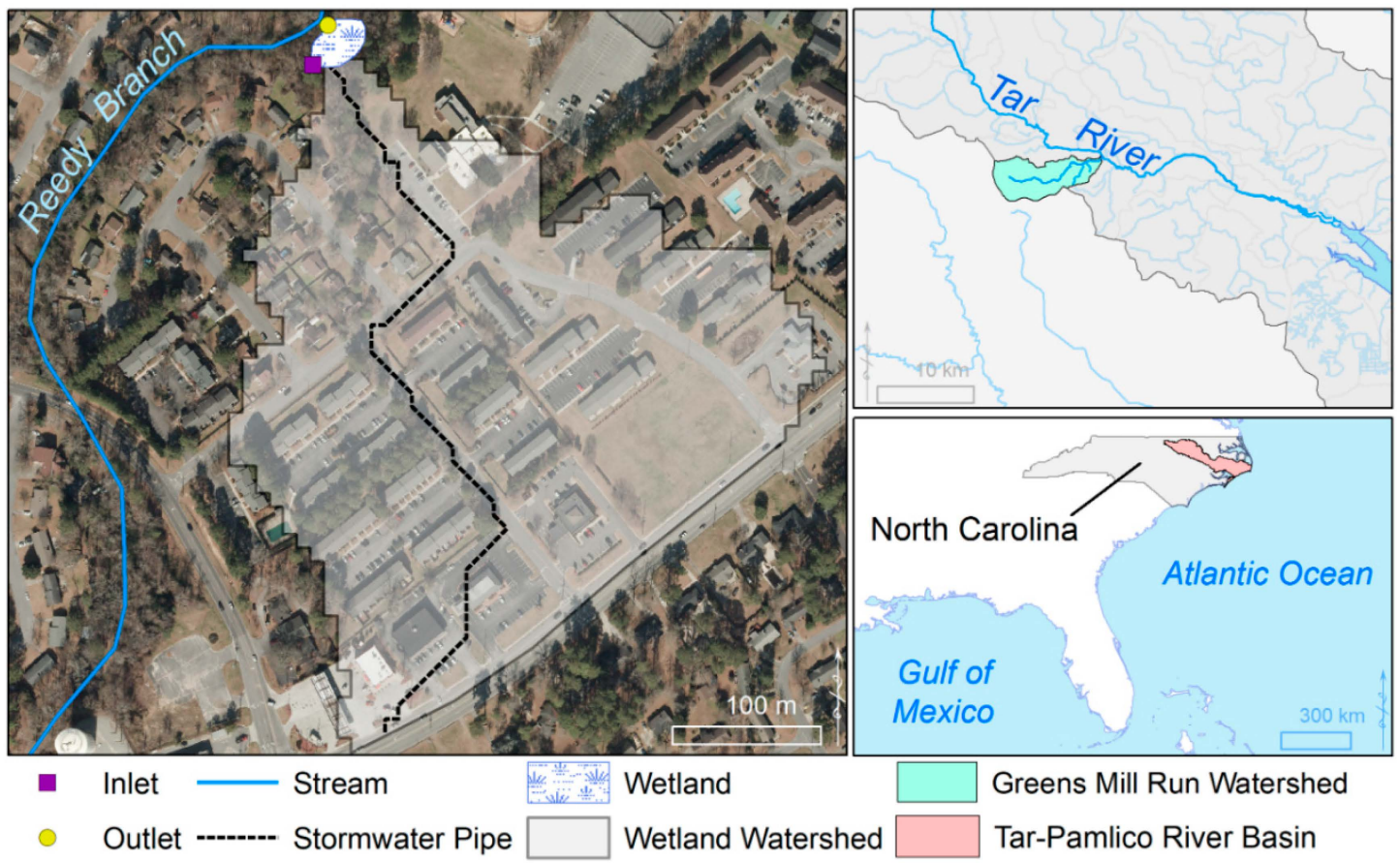

Figure 1. Watershed for a stormwater control measure (dry detention basin converted to a wetland) at Jaycee Park in the City of Greenville, NC, USA. The control measure discharges effluent to Reedy Branch, a Tributary of Greens Mill Run and the Tar River.

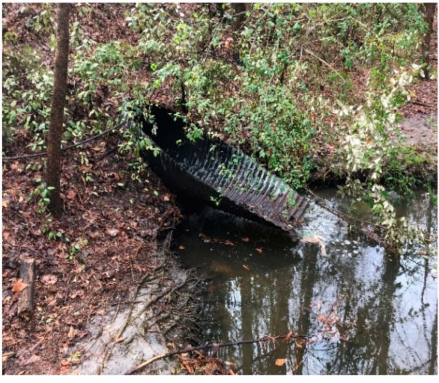

(a)

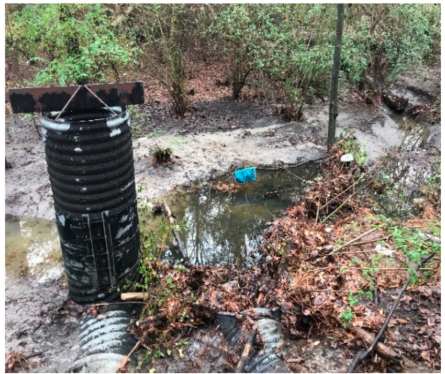

(c)

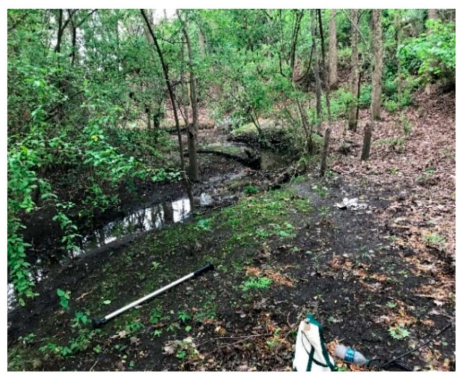

(b)

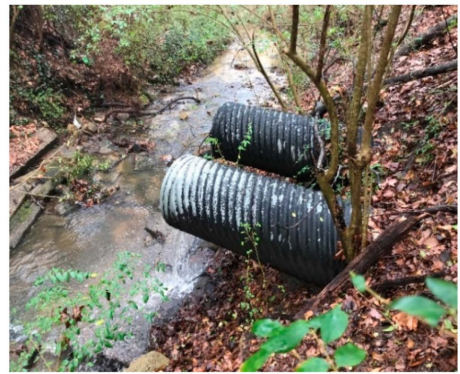

(d)

Figure 2. Dry detention basin inlet (a), interior (b), outlet structures (c) and discharge pipes (d) to Reedy Branch. Photographs were captured by the authors.

\subsection{Wetland Conversion}

The conversion of the dry detention basin to a wetland occurred between December 2018 and February 2019 (Figure 3). The retrofit included removal of underbrush, invasive shrubs, and sediment. A more defined forebay lined with rip-rap and a sinuous shallow water zone connecting the inlet and outlet was constructed. A new outlet structure was installed and wetland trees and live-stakes were planted along the banks of the shallow water zone and shallow land areas. The new outlet structure 
included a single overflow riser encompassing the two existing $0.6 \mathrm{~m}$ diameter outlet pipes. The outlet riser had two draw downpipes at different elevations connected to the structure (Figure 4). The lower draw downpipe was constructed using $10 \mathrm{~cm}$ diameter PVC and placed approximately $0.35 \mathrm{~m}$ above the base of the main outlet pipes and $0.15 \mathrm{~m}$ below the second draw downpipe. The second draw downpipe was made using $7.5 \mathrm{~cm}$ diameter aluminum pipe. These smaller diameter pipes were installed to slow the release of stormwater, thus increasing residence time.

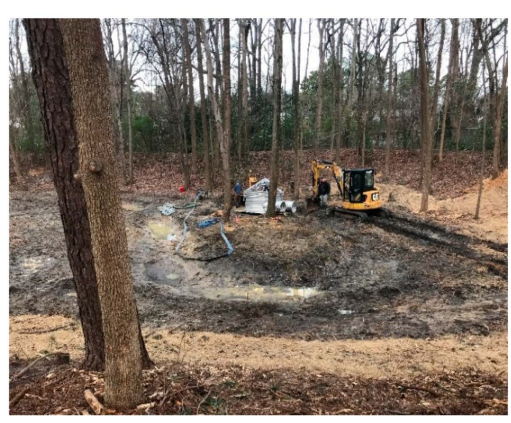

(a)

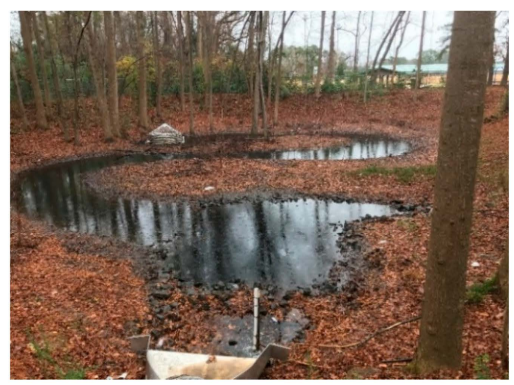

(c)

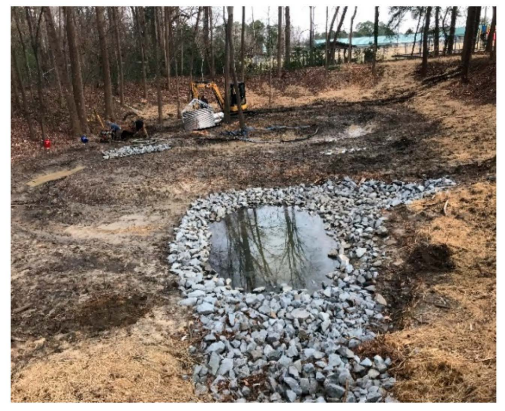

(b)

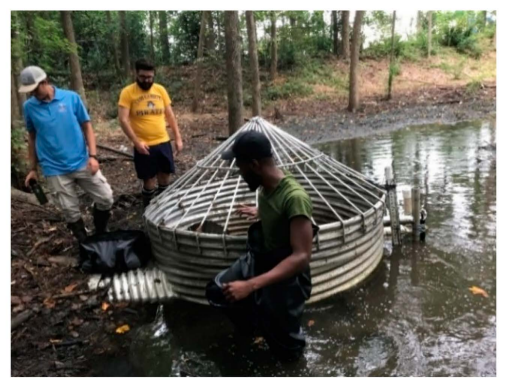

(d)

Figure 3. A new longer and meandering channel connecting the inlet to the outlet was created using an excavator (a). A forebay lined with rip rap was installed near the inlet (b). A new inlet structure with a flange was installed (c) and a new outlet structure with trash guard, and two draw downpipes were installed (d). Photographs were captured by the authors.

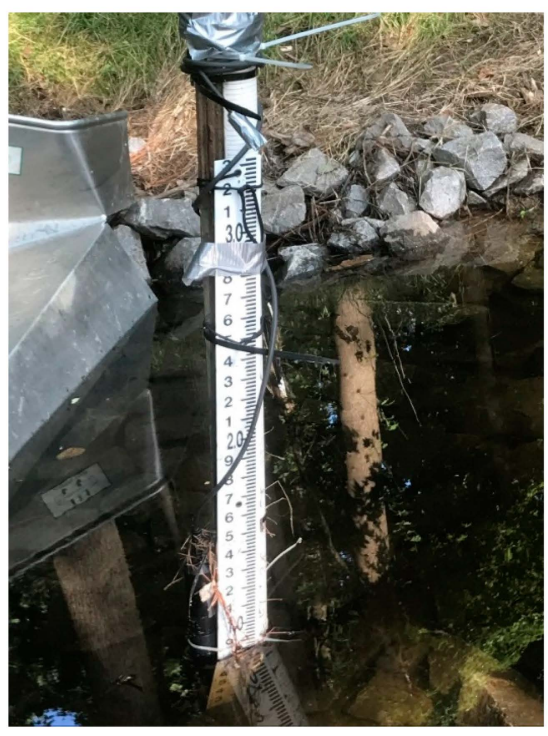

(a)

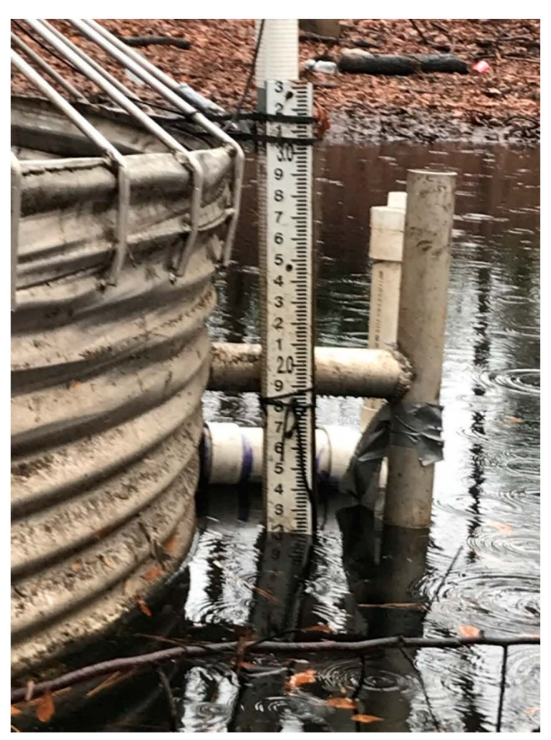

(b)

Figure 4. Stilling well with stage plate installed near the inlet of the wetland (a). Stilling well with stage plate installed near outlet pipes of wetland (b). Photographs were captured by the authors. 


\subsection{Sample Collection}

Water samples were collected from the inlet and outlet locations of the SCMs during 23 different storms over the course of the study. These included 13 different storms sampled pre conversion between February and December 2018. Ten storms were sampled post conversion between February 2019 and February 2020. Samples were collected for dissolved nitrogen and carbon analyses using 250or 500-mL HDPE bottles. Samples were collected during different times and (water level) stages of the storms at the inlet and outlet of the dry detention basin and the wetland. Samples were placed in ice-filled coolers and were transported to the lab for analyses.

\subsection{Water Quality Analyses}

Samples were analyzed for $\mathrm{NH}_{4}{ }^{-} \mathrm{N}, \mathrm{NO}_{3}{ }^{-} \mathrm{N}$, total dissolved nitrogen (TDN), chloride (Cl), and dissolved organic carbon (DOC) at the East Carolina University Environmental Research Laboratory. Water samples were filtered first using using Watman 934-AH $1.5 \mu \mathrm{m}$ and then Whatman GF/F $0.7 \mu \mathrm{m}$ pore-size filters. The filtrate was analyzed using a Unity SmartChem 200 analyzer to determine $\mathrm{NH}_{4}{ }^{-} \mathrm{N}, \mathrm{NO}_{3}{ }^{-} \mathrm{N}$, and $\mathrm{Cl}$ concentrations while a Shimadzu TNN-L analyzer using catalytic thermal decomposition/chemiluminescence was used for determining TDN and DOC concentrations.

Autonomous physicochemical loggers from Hanna Instruments (HI 9829) were deployed at the inlet and outlet of the SCM prior to storm events. The loggers were programmed to record dissolved oxygen (DO), temperature, $\mathrm{pH}$, and oxidation reduction potential (ORP) every $10 \mathrm{~min}$.

\subsection{Flow Measurements}

Water level loggers (Solinst Levelogger 3001) were installed in stilling wells attached to posts near the inlet and outlet of the basin (Figure 4). Also attached to each post was a stage plate. The loggers were programmed to record levels every $10 \mathrm{~min}$ and were downloaded every 3 months. During sample collection, the stage of water was recorded and used to calibrate the logger readings to allow for a continuous record of water stage. Inflow and outflow $\left(\mathrm{L} \mathrm{s}^{-1}\right)$ were determined by multiplying velocity by a cross-sectional area of water at the inlet and outlet pipes. A Global Water FP101 flow probe was used to determine velocity, and a measuring rod was used to determine mean depth and width of water in the inflow and outflow pipes. A stage-discharge curve was developed using the manual flow measurements and stage readings during sampling events. Runoff volumes entering the control measure from rain events were estimated using the Simple Method [25]. Rain data were accessed from the USGS gauge on the Tar River in Greenville, NC [26]. Drawdown times for the dry detention basin and wetland were compared to assess whether differences in residence times were observed for similar size rain events.

\subsection{Statistical Comparisons}

Concentrations of TDN, DOC, $\mathrm{NH}_{4}-\mathrm{N}$, and $\mathrm{NO}_{3}{ }^{-} \mathrm{N}$ for the inflow and outflow were compared for the dry detention basin and the wetland. Because there were often multiple inflow/outflow samples per storm event, flow-weighted concentrations were calculated and used for statistical comparisons. Differences in the median flow-weighted concentrations between inflow and outflow were reported. Anderson-Darling tests of normality showed that most data did not follow a normal distribution. Therefore, Mann-Whitney non-parametric tests were used to determine whether differences between inflow and outflow parameters were statistically significant $(p<0.05)$. Outflow concentrations pre and post retrofit and inflow (pre and post) were also compared. The frequency that outflow concentrations were lower than inflow concentrations for pre and post retrofit were reported. Physicochemical properties of inflow and outflow were also compared. Statistical analyses were performed using Minitab 18 and $R$ statistical software. 


\section{Results}

\subsection{Nitrogen Treatment by Dry Detention Basin and Wetland}

The median flow weighted TDN concentrations at the inlet and the outlet of the dry detention basin were identical (0.47 $\mathrm{mg} \mathrm{L}^{-1}$ ) (Figure 5). During 39\% of sampling events, the outflow concentrations were higher relative to inflow (Figure 6). The highest TDN removal rate for the basin occurred during May of 2018. Inflow and outflow from the basin were sampled during a few different May storms, producing between 0.2 and $2.4 \mathrm{~cm}$ of rain, and the median treatment efficiency was $64 \%$. The lowest TDN removal rate for the basin occurred a few months later during the summer of 2018. Inflow and outflow were associated with 3 different storms in July, producing between 1.3 and $4.3 \mathrm{~cm}$ of rain and resulting in TDN exports four times greater than the inflow. These more intense, larger rain events quickly flushed through the basin with little opportunity for nitrogen transformations. Overall, the median flow weighted $\mathrm{NO}_{3}{ }^{-} \mathrm{N}$ concentration at the outlet $\left(0.13 \mathrm{mg} \mathrm{L}^{-1}\right)$ was about $13 \%$ lower than at the inlet $\left(0.15 \mathrm{mg} \mathrm{L}^{-1}\right)$. During $61 \%$ of events, the inlet concentrations of $\mathrm{NO}_{3}{ }^{-} \mathrm{N}_{\text {were higher than }}$ the outlet. Median flow weighted $\mathrm{NH}_{4}{ }^{+} \mathrm{N}$ concentrations at the inlet $\left(0.17 \mathrm{mg} \mathrm{L}^{-1}\right)$ were $17.6 \%$ higher relative to the outlet $\left(0.14 \mathrm{mg} \mathrm{L}^{-1}\right)$ and during $54 \%$ of sampling events, the inflow concentrations were higher than the outflow. However, there was no statistical significance $(p>0.05)$ between inflow and outflow concentrations for any of the nitrogen species. These data suggest that overall, the dry detention basin was not effective at treating any form of dissolved nitrogen.

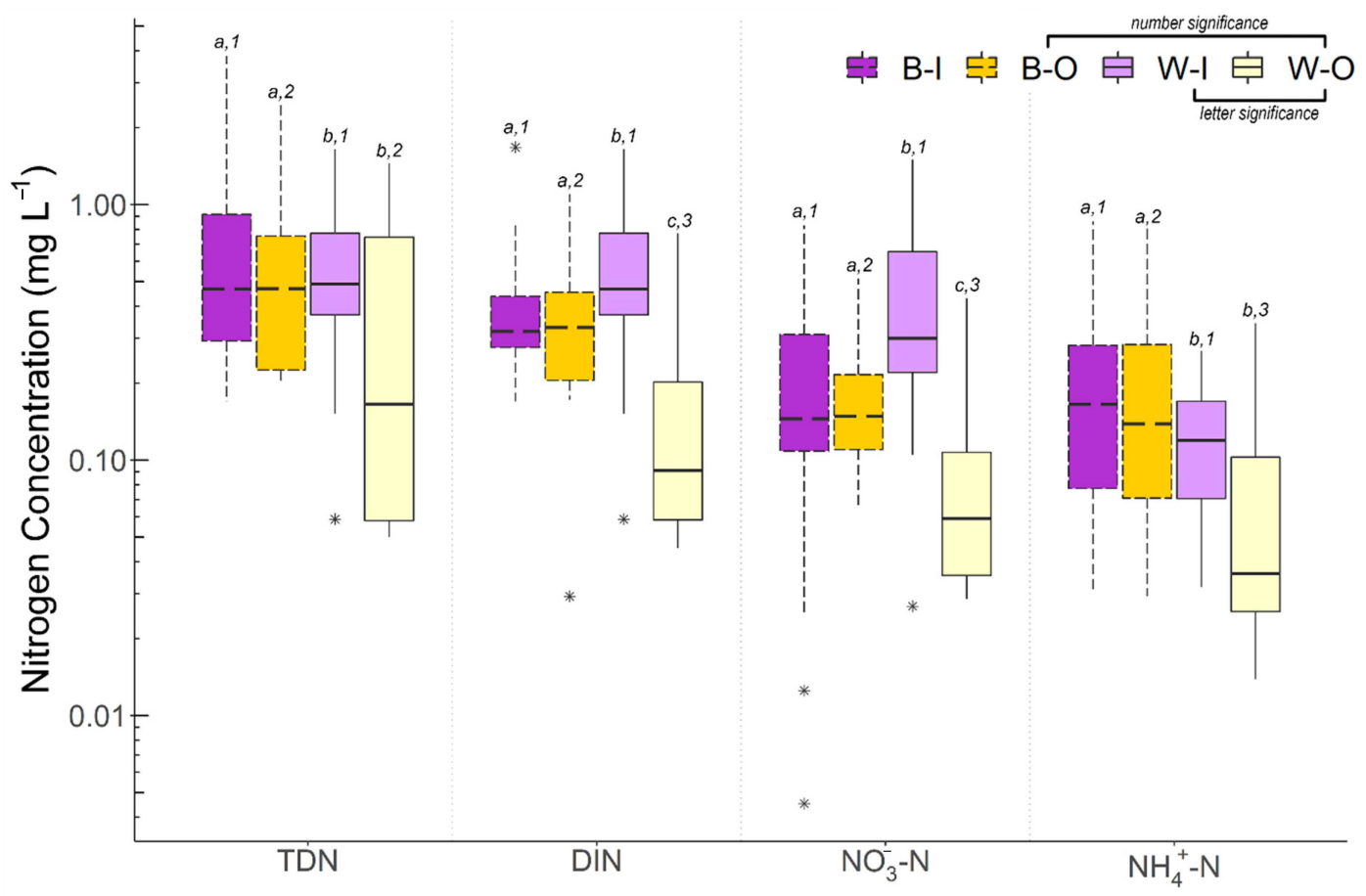

Figure 5. Boxplots of flow-weighted concentrations of total dissolved nitrogen (TDN), dissolved inorganic nitrogen (DIN), nitrate $\left(\mathrm{NO}_{3}{ }^{-} \mathrm{N}\right)$, and ammonium $\left(\mathrm{NH}_{4}{ }^{+} \mathrm{N}\right)$ at the inlet (I) and outlet $(\mathrm{O})$ of the dry basin $(\mathrm{B})$ and wetland $(\mathrm{W})$. Letter changes indicate significant intra-control measure differences in concentrations. The number of changes indicate significant inter-control measure differences in concentrations. Statistical outliers indicated by $\left({ }^{*}\right)$. 

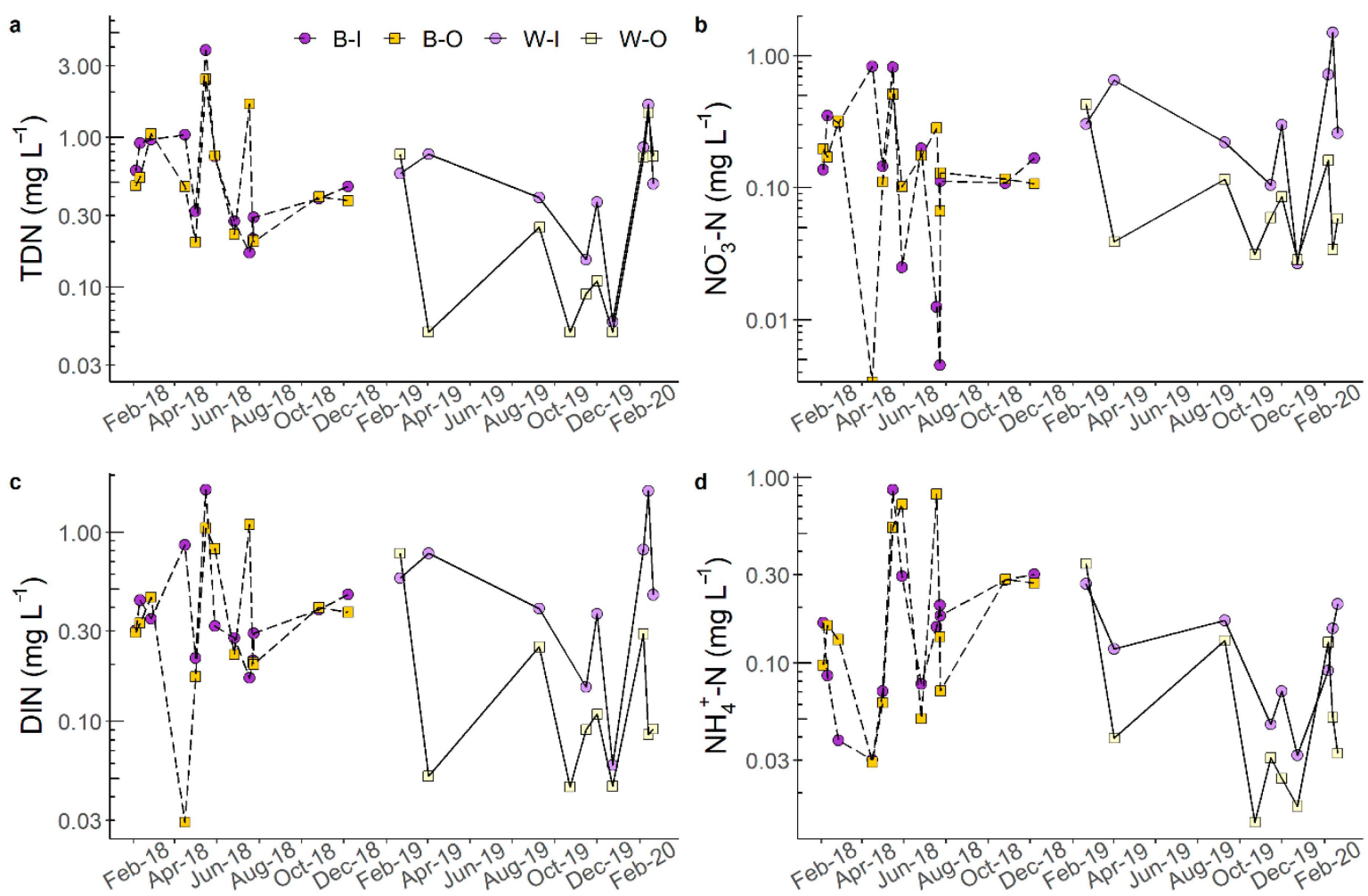

Figure 6. Line plots of flow-weighted concentrations of total dissolved nitrogen (TDN) (a), nitrate $\left(\mathrm{NO}_{3}{ }^{-} \mathrm{N}\right)(\mathbf{b})$, dissolved inorganic nitrogen (DIN) (c), and ammonium $\left(\mathrm{NH}_{4}{ }^{+} \mathrm{N}\right)(\mathbf{d})$, at the inlet (I) and outlet $(\mathrm{O})$ of the dry basin $(\mathrm{B})$ and wetland $(\mathrm{W})$.

The median flow weighted concentration of TDN at the wetland outlet $\left(0.18 \mathrm{mg} \mathrm{L}^{-1}\right)$ was $63 \%$ lower relative to the inlet $\left(0.49 \mathrm{mg} \mathrm{L}^{-1}\right)$, and during $87.5 \%$ of sampling events, the outflow concentration of TDN was lower than the inflow. The highest TDN removal rate for the basin occurred in April of 2019 during a $2.1 \mathrm{~cm}$ rain event. Outflow concentrations were $94 \%$ lower relative to inflow during that period. The lowest median TDN removal rates occurred in February of 2020. Median outflow concentrations of TDN associated with storms producing between 0.4 to $4.3 \mathrm{~cm}$ of rain were $15 \%$ lower relative to inflow. Overall, the wetland was a sink for $\mathrm{NH}_{4}{ }^{+} \mathrm{N}$ and $\mathrm{NO}_{3}{ }^{-} \mathrm{N}$ during $75 \%$ and $87.5 \%$ respectively, of sampling events. Median inflow concentrations of $\mathrm{NH}_{4}{ }^{+} \mathrm{N}\left(0.12 \mathrm{mg} \mathrm{L}^{-1}\right)$ and $\mathrm{NO}_{3}{ }^{-} \mathrm{N}$ $\left(0.30 \mathrm{mg} \mathrm{L}^{-1}\right)$ were higher relative to outflow concentrations $\left(0.04 \mathrm{mg} \mathrm{L}^{-1}\right.$ of $\mathrm{NH}_{4}^{+} \mathrm{N} ; 0.06 \mathrm{mg} \mathrm{L}^{-1}$ of $\mathrm{NO}_{3}{ }^{-} \mathrm{N}$ ). Differences in concentrations of $\mathrm{NO}_{3}{ }^{-} \mathrm{N}$ in the outflow and inflow were statistically significant $(p=0.025)$, but differences in $\mathrm{NH}_{4}+\mathrm{N}$ were not $(p=0.079)$. Both $\mathrm{NH}_{4}{ }^{+} \mathrm{N}$ and $\mathrm{NO}_{3}{ }^{-} \mathrm{N}$ are biologically reactive species of nitrogen, and together comprise dissolved inorganic nitrogen (DIN). There were statistically significant differences $(p=0.016)$ in concentrations of DIN when comparing inflow $(0.46 \mathrm{mg}$ $\left.\mathrm{L}^{-1}\right)$ and outflow $\left(0.09 \mathrm{mg} \mathrm{L}^{-1}\right)$. Outflow DIN concentrations were lower than inflow concentrations during $87.5 \%$ of sampling events. Inflow DIN concentrations for the dry detention basin $\left(0.32 \mathrm{mg} \mathrm{L}^{-1}\right)$ were not significantly different $(p=0.385)$ than inflow DIN concentrations for the wetland $(0.47 \mathrm{mg}$ $\left.\mathrm{L}^{-1}\right)$. However, outflow DIN concentrations for the wetland $\left(0.09 \mathrm{mg} \mathrm{L}^{-1}\right)$ were significantly lower $(p=0.020)$ than outflow concentrations for the dry detention basin $\left(0.33 \mathrm{mg} \mathrm{L}^{-1}\right)$ (Figure 5). Differences in the median TDN to $\mathrm{Cl}$ ratio between inflow and outflow for the wetland (57\%) were greater relative to the basin (51\%), also indicating better removal of nitrogen for the wetland [27].

\subsection{DOC in Dry Detention and Wetland}

Median flow-weighted concentration of DOC at the inlet of the dry detention basin $\left(5.83 \mathrm{mg} \mathrm{L}^{-1}\right)$ was elevated relative to the outlet concentration $\left(5.58 \mathrm{mg} \mathrm{L}^{-1}\right)$, but differences were not statistically significant (Figure 7). During 67\% of sampling events, the inflow concentration of DOC was higher 
than the outflow concentration (Figure 7). In contrast, the median outflow concentration of DOC at the wetland $\left(7.1 \mathrm{mg} \mathrm{L}^{-1}\right)$ was elevated relative to the inlet concentration $\left(6.6 \mathrm{mg} \mathrm{L}^{-1}\right)$. During $75 \%$ of sampling events, the outflow concentration was higher than the inflow concentration. These results show that after the basin was converted to a wetland, the SCM more frequently exported DOC.
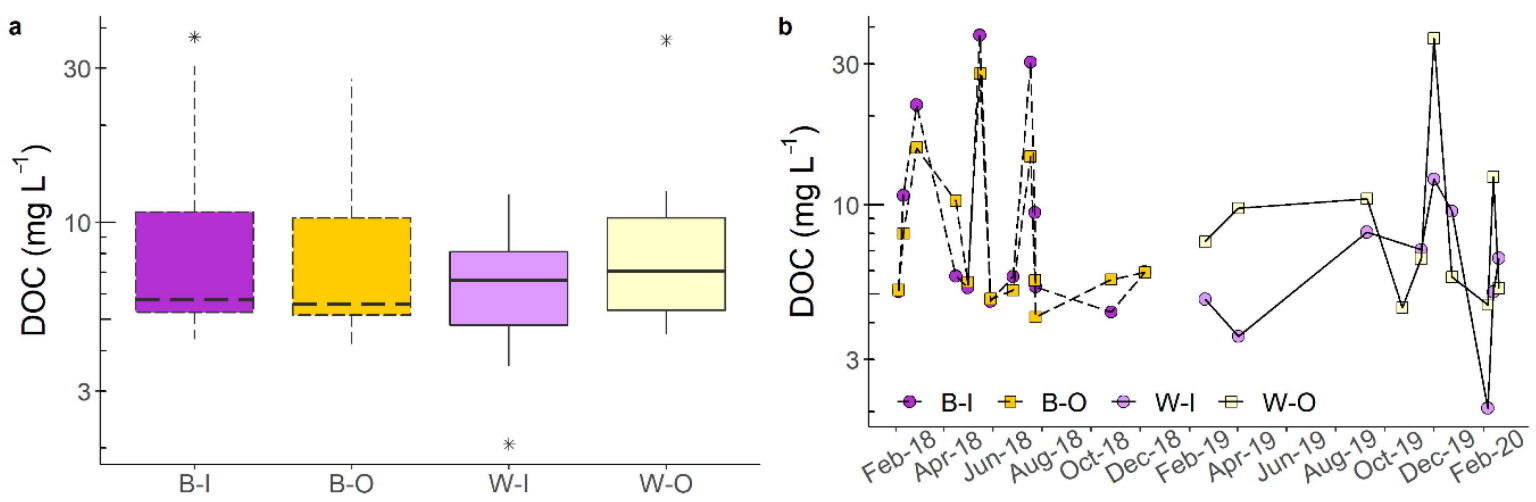

Figure 7. Boxplots (a) and line plots (b) of flow weighted concentrations of dissolved organic carbon (DOC) at the inlet (I) and outlet (O) of the dry basin (B) and wetland (W). Statistical outliers represented by $\left({ }^{*}\right)$.

\subsection{High-Frequency Physicochemical Characteristics of Inflow and Outflow}

\subsubsection{Flow Characteristics}

Outflow from the wetland following a rain event lasted an order of magnitude (or more) longer relative to outflow for the basin. For example, during a $3.7 \mathrm{~cm}$ rain event in September of 2018 that produced an estimated $1650 \mathrm{~m}^{3}$ of runoff entering the basin, the outflow stage for the basin reached a peak of $152.9 \mathrm{~cm}$ and declined to $25.8 \mathrm{~cm}$ in $4.5 \mathrm{~h}$ (Figure 8). A similar-scale rain event $(4.3 \mathrm{~cm}$ ) producing $1911 \mathrm{~m}^{3}$ or runoff entering the wetland occurred in September of 2019, and the outlet stage exceeded $103 \mathrm{~cm}$ and declined to $56 \mathrm{~cm}$ after $116 \mathrm{~h}$. In November of 2018, a $1.1 \mathrm{~cm}$ rain event producing $486 \mathrm{~m}^{3}$ of runoff resulted in a peak water stage at the outlet of the basin of $107 \mathrm{~cm}$ (Figure 9). The stage declined to $20 \mathrm{~cm}$ within $80 \mathrm{~min}$. In November 2019, a $1.1 \mathrm{~cm}$ rain event producing $486 \mathrm{~m}^{3}$ of runoff resulted in an outlet stage peak of $102 \mathrm{~cm}$ for the wetland, and the stage declined to $41.4 \mathrm{~cm} 90 \mathrm{~h} \mathrm{later}$. In December 2018, a $0.6 \mathrm{~cm}$ rain event producing $271 \mathrm{~m}^{3}$ of runoff resulted in a peak stage near the basin outlet of $31.7 \mathrm{~cm}$, and $4.67 \mathrm{~h}$ later the stage had lowered to $18.1 \mathrm{~cm}$ (Figure 10). During a $0.6 \mathrm{~cm}$ rain event in December 2019, runoff entering the basin was estimated to be $271 \mathrm{~m}^{3}$ and the peak stage near the outlet of wetland was $67.8 \mathrm{~cm}$. The stage declined from the maximum of $67.8 \mathrm{~cm}$ to $42 \mathrm{~cm}$ in just over $100 \mathrm{~h}$. The differences in water level recession for the basin and wetland can be more easily quantified by reviewing the slopes of regression lines during each of the similar-sized storms. There was more than one order of magnitude difference in the slopes of regression lines for each event (Figures 8-10). The residence time of stormwater in the wetland was much greater in comparison to the basin. There were significant correlations between stage $(\mathrm{cm})$ and outflow $\left(\mathrm{L} \mathrm{s}^{-1}\right)$ for the basin $(p=0.005)$ and wetland $(p<0.001)$. Therefore, as the stage increased and decreased in response to runoff, so too did the outflow. Overall, the mean storm size sampled for the dry basin and wetland were $1.6 \mathrm{~cm}$ and $1.3 \mathrm{~cm}$ of rain, respectively. The maximum storm size sampled was $4.3 \mathrm{~cm}$ for both, and the smallest rain event sampled for the basin $(0.2 \mathrm{~cm})$ and wetland $(0.4 \mathrm{~cm})$ were similar. 

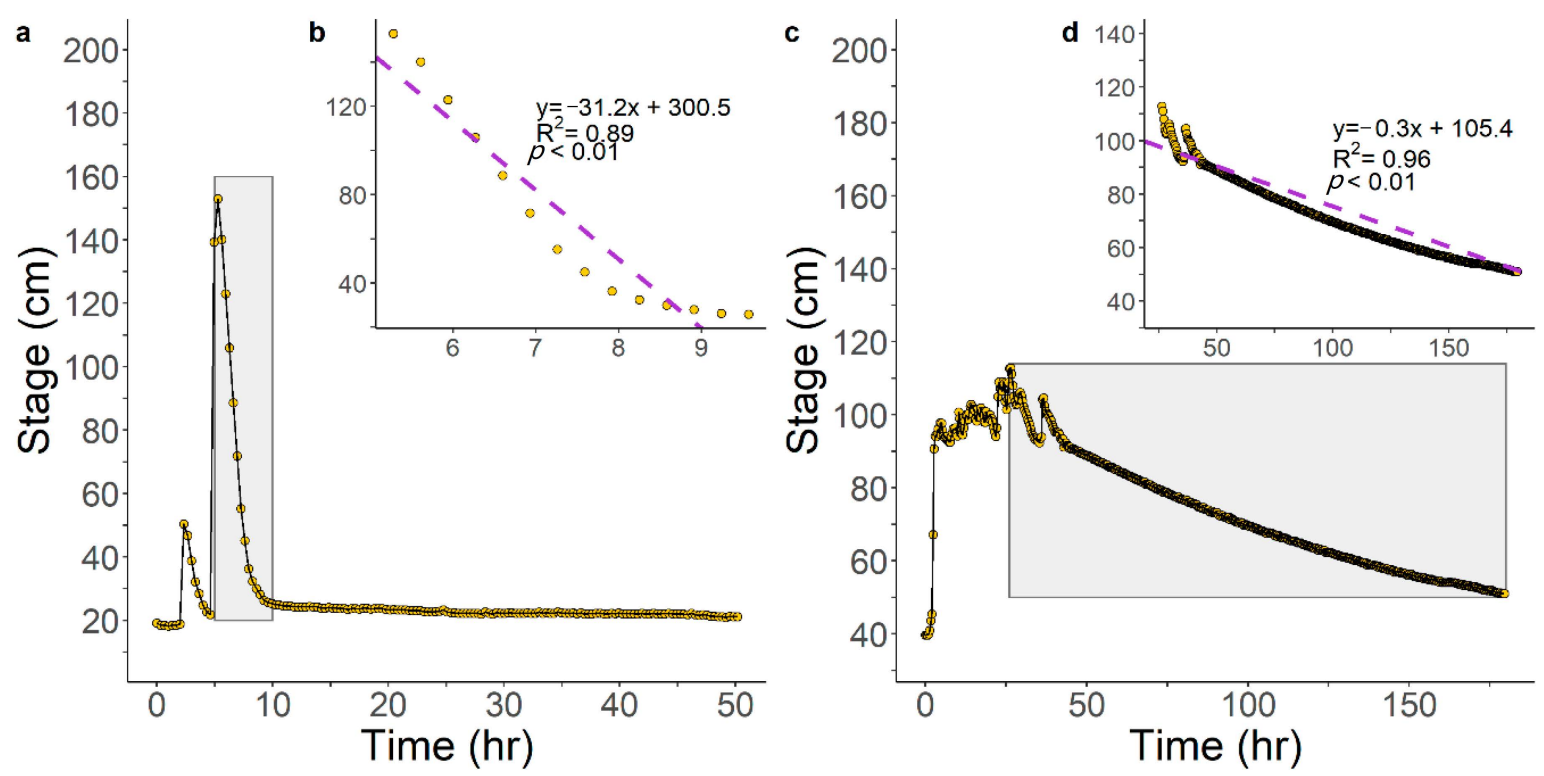

Figure 8. Outlet stage response to a $3.7 \mathrm{~cm}$ rain event in September of 2018 for the dry detention basin (a,b). Outlet stage response to a $4.3 \mathrm{~cm}$ rain event for the wetland in September of 2019 (c,d). The slope of the stage decline for the basin (b) was 2 orders of magnitude steeper than the wetland (d). Grey-shaded boxes denote range of inset graphs $(\mathbf{b}, \mathbf{d})$.
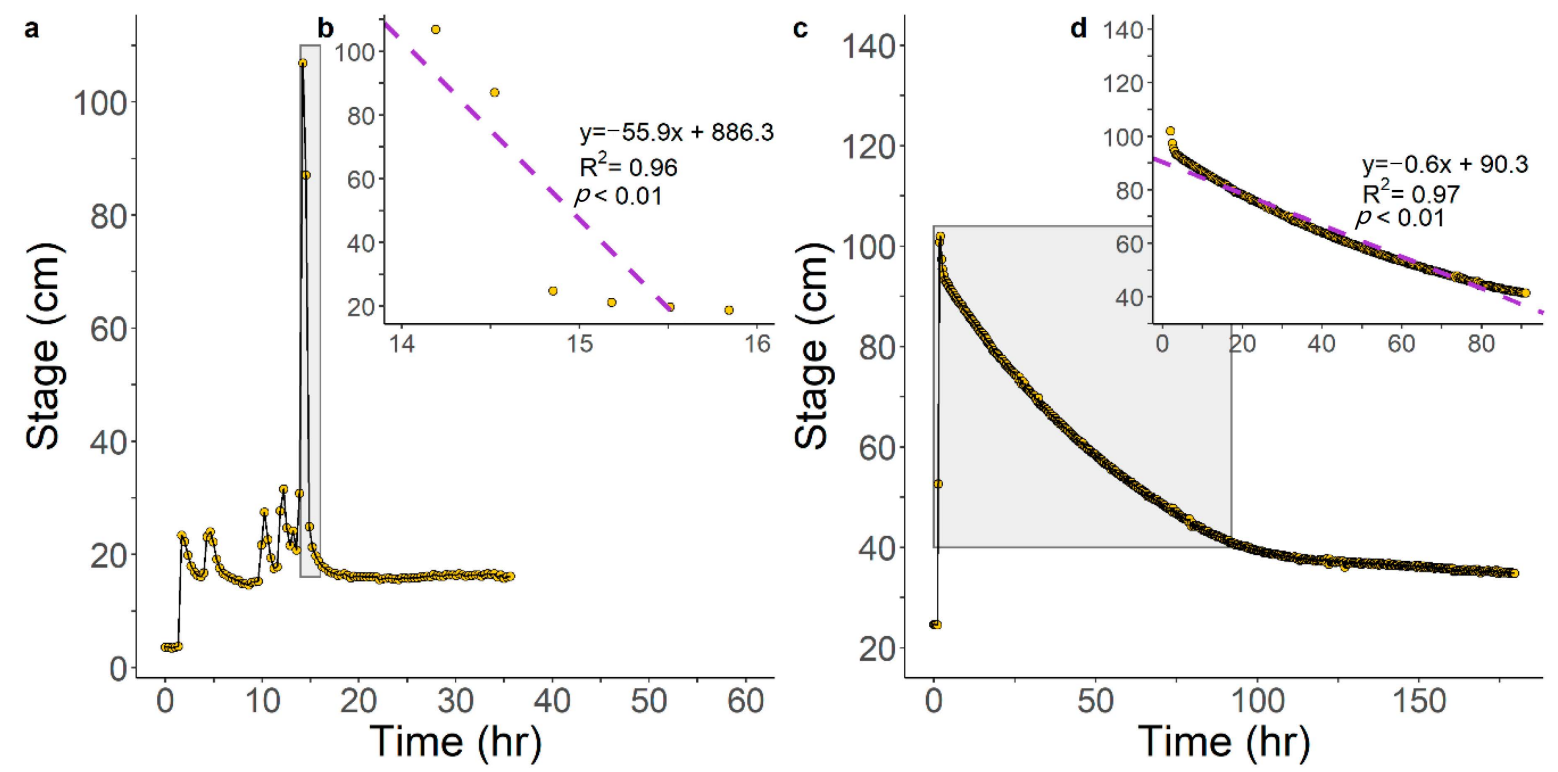

Figure 9. Outlet stage response to a $1.1 \mathrm{~cm}$ rain event in November of 2018 for the dry detention basin $(\mathbf{a}, \mathbf{b})$. Outlet stage response to a $1.1 \mathrm{~cm}$ rain event for the wetland in November of 2019 (c,d). The slope of the stage decline for the basin (b) was almost 2 orders of magnitude steeper than the wetland (d). Grey-shaded boxes denote range of inset graphs $(\mathbf{b}, \mathbf{d})$. 

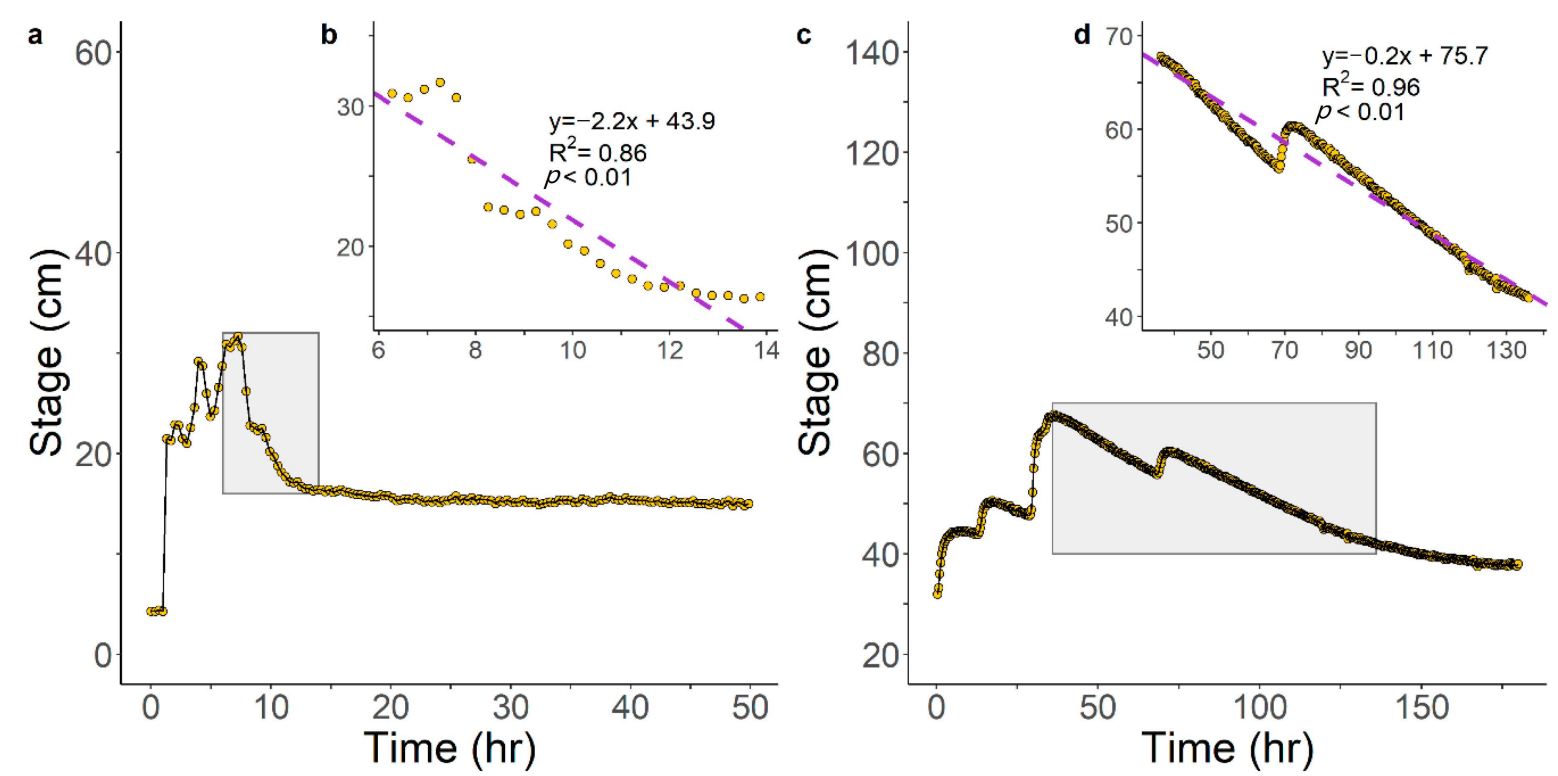

Figure 10. Outlet stage response to a $0.6 \mathrm{~cm}$ rain event in December of 2018 for the dry detention basin $(\mathbf{a}, \mathbf{b})$. Outlet stage response to a $0.6 \mathrm{~cm}$ rain event for the wetland in December of 2019 (c,d). The slope of the stage decline for the basin (b) was 1 order of magnitude steeper than the wetland (d). Grey-shaded boxes denote range of inset graphs $(\mathbf{b}, \mathbf{d})$.

\subsection{2. $\mathrm{pH}$}

The median $\mathrm{pH}$ of inflow (6.6) and outflow (6.5) for the dry basin were alike (Table 1). During 60\% of storm events sampled, the inflow $\mathrm{pH}$ was greater than the outflow $\mathrm{pH}$. The median $\mathrm{pH}$ of wetland inflow (6.6) was elevated relative to basin outflow (5.7), and during each storm sampled, the inflow $\mathrm{pH}$ was greater than the outflow $\mathrm{pH}$. The median $\mathrm{pH}$ of inflow for the basin and wetland were identical (6.6) and similar to the median $\mathrm{pH}$ of basin outflow (6.5) and elevated relative to wetland outflow (5.7). These results suggest that biochemical processes were not as active for the basin relative to the wetland.

Table 1. Median and range of physicochemical readings for the inlet and outlet of the dry detention basin and wetland. Frequencies that the inlet (I) values exceeded the outlet values are reported. Differences in outflow concentrations for the basin $(B)$ in relation to the wetland $(W)$ were also reported.

\begin{tabular}{cccc}
\hline Location & $\mathbf{p H}$ & DO $\left(\mathbf{m g ~ L}^{-\mathbf{1}}\right)$ & ORP (mV) \\
\hline Dry Basin Inlet & $6.6(5.3,7.0)$ & $9.1(2.7,15.7)$ & $99.6(67.0,261.7)$ \\
Dry Basin Outlet & $6.5(5.2,7.1)$ & $9.0(0.1,18.4)$ & $218.6(145.0,374.7)$ \\
Difference & 0.1 & 0.1 & 119 \\
Freq I > O & 60 & 0 & 0 \\
\hline Wetland Inlet & $6.6(6.3,7.2)$ & $5.2(0.1,10.8)$ & $61.3(-81.4,659.2)$ \\
Wetland Outlet & $5.7(5.4,6.9)$ & $1.1(0.1,11.5)$ & $-80.0(-978.3,322.5)$ \\
Difference & 0.9 & 4.1 & 141.3 \\
Freq I > O & 100 & 85 & 37.5 \\
\hline Dry Basin Outlet & 6.5 & 9 & 218.6 \\
Wetland Outlet & 5.7 & 1.1 & -80 \\
Difference (B-W) & 0.8 & 7.9 & 298.6 \\
\hline
\end{tabular}

\subsubsection{Dissolved Oxygen}

The median overall concentration of DO at the inlet $\left(9.1 \mathrm{mg} \mathrm{L}^{-1}\right)$ and outlet $\left(9.0 \mathrm{mg} \mathrm{L}^{-1}\right)$ of the dry detention basin were alike (Table 1). During each of the storm events when the autonomous loggers were deployed, the median outflow concentration of DO was elevated relative to the inflow (Table 1 ). The median DO concentration at the outlet of the wetland $\left(1.1 \mathrm{mg} \mathrm{L}^{-1}\right)$ was significantly $(p<0.001)$ 
lower relative to the inlet $\left(5.2 \mathrm{mg} \mathrm{L}^{-1}\right)$. During $85 \%$ of storms monitored, the inflow DO concentration exceeded the outflow (Table 1). Differences in the median concentration of DO between the inlet and the outlet of the dry detention basin were less than $0.2 \mathrm{mg} \mathrm{L}^{-1}$, while there was a $4.1 \mathrm{mg} \mathrm{L}^{-1}$ difference when comparing inlet and outlet for the wetland (Table 1). The outflow concentration of DO for the wetland was significantly lower $(p<0.001)$ in comparison to outflow from the dry detention basin.

\subsubsection{Oxidation Reduction Potential}

The median ORP at the outlet of the dry detention basin was elevated relative to the inlet for each storm that was monitored (Table 1$)$. Overall, there were significant differences $(p<0.001)$ in ORP values when comparing the median inlet $(99.6 \mathrm{mV})$ and outlet $(218.6 \mathrm{mV})$ values for the basin. When pooling all data, the ORP at the wetland outlet $(-80 \mathrm{mV})$ was significantly lower $(p<0.001)$ relative to the inlet $(61 \mathrm{mV})$. The median ORP of wetland outflow $(-80 \mathrm{mV})$ was nearly $300 \mathrm{mV}$ lower relative to the basin outflow $(218.6 \mathrm{mV})$, and differences in ORP were statistically significant $(p<0.001)$ (Table 1). There was a 39-mV difference in ORP when comparing the median values for the basin inlet $(99.6 \mathrm{mV})$ and wetland inlet $(61.3 \mathrm{mV})$ and the differences were also statistically significant $(p<0.001)$.

\section{Discussion}

Inflow and outflow concentrations of TDN from the dry detention basin were similar, indicating poor treatment of nitrogen by the basin. After the basin was converted to a wetland, the treatment efficiency of the SCM increased, and the quality of water entering Reedy Branch improved. More specifically, discharge from the wetland had TDN and DIN concentrations that were 63\% and $81 \%$ lower relative to wetland inflow. Furthermore, median concentrations of TDN and DIN in outflow from the wetland were nearly $66 \%$ and $73 \%$ lower relative to outflow from the basin. While the authors did not have the analytical laboratory capacity to directly measure dissolved organic nitrogen $(\mathrm{DON})$, an estimate of DON may be calculated by subtracting DIN $\left(\mathrm{NH}_{4}{ }^{+}\right.$and $\left.\mathrm{NO}_{3}{ }^{-}\right)$from TDN. Based on these estimates, the median influent and effluent concentration of DON for the dry basin were similar, with $0.01 \mathrm{mg} \mathrm{L}^{-1}$ more DON entering in comparison to exiting the basin. Differences in the estimated median DON concentration entering and exiting the wetland were larger, with $0.09 \mathrm{mg} \mathrm{L}^{-1}$ more DON leaving the wetland than entering. Therefore, while the wetland was most often a sink for DIN, it was a source of DON.

Most of the reduction in TDN concentrations for the wetland could be attributed to $\mathrm{NO}_{3}{ }^{-}$ reduction. There was a decrease in $\mathrm{NO}_{3}{ }^{-}$concentration of $0.24 \mathrm{mg} \mathrm{L}^{-1}$ when comparing outflow to inflow concentrations for the wetland, while $\mathrm{NH}_{4}{ }^{+}$concentrations decreased by $0.08 \mathrm{mg} \mathrm{L}^{-1}$. It is likely that the mechanism for $\mathrm{NO}_{3}{ }^{-}$removal within the wetland was denitrification. Denitrification is the conversion of $\mathrm{NO}_{3}{ }^{-}$to $\mathrm{N}_{2}$ or $\mathrm{N}_{2} \mathrm{O}$, and requires anaerobic conditions, $\mathrm{NO}_{3}{ }^{-}$, a source of carbon to serve as the energy sources and electron donor, suitable environmental conditions (e.g., $\mathrm{pH}$, temperature), and time for microbial activity $[12,19,28]$. These requirements were present in the wetland. For example, the median DO concentration in wetland outflow was $4.1 \mathrm{mg} \mathrm{L}^{-1}$ lower than the median inflow concentration (Table 1). The median ORP of wetland outflow was almost $300 \mathrm{mV}$ lower in comparison to the median basin outflow, and $141 \mathrm{mV}$ lower than wetland inflow. Thus, the lowered (relative to inlet) DO and ORP values in the wetland outflow indicates that the wetland was a reducing environment, where conversion of $\mathrm{NO}_{3}{ }^{-}$to $\mathrm{N}_{2}$ may occur $[19,28]$. The median DOC concentration in wetland outflow was greater in comparison to wetland inflow, and dry basin inflow and outflow. The increase in DOC for wetland outflow may be related to leaves, pine straw, and other organic debris that enters the wetland and sinks or is too large to pass through the small outlet pipes and decomposes, releasing DOC. These processes may also have contributed to the net export of DON from the wetland. The median concentration of $\mathrm{NO}_{3}{ }^{-}$in wetland influent was $0.30 \mathrm{mg} \mathrm{L}^{-1}$ and the median DOC concentration in wetland outflow was $7.1 \mathrm{mg} \mathrm{L}^{-1}$, resulting in a DOC to $\mathrm{NO}_{3}$ ratio of 23:1. Based on that ratio, denitrification would not likely have been limited by carbon in the wetland [20,29]. Water temperatures exceeded $2{ }^{\circ} \mathrm{C}$ for each storm sampled during the study, thus environmental 
conditions including temperature were conducive in the wetland for the denitrification process [21]. The $\mathrm{pH}$ of wetland inflow and outflow was greater than 4.5 , thus $\mathrm{pH}$ was in the range suitable for nitrogen transformations by microorganisms [21]. The residence time of water in the wetland was more than an order of magnitude greater in comparison to the residence time in the basin. There was more time and opportunity for carbon and nitrogen transformations in the wetland relative to the basin. There was also a reduction in the median concentration of $\mathrm{NH}_{4}{ }^{+}$when comparing outflow to inflow concentrations in the wetland. Potential removal mechanisms for $\mathrm{NH}_{4}{ }^{+}$include immobilization via plant uptake and adsorption onto cation exchange sites. It is also possible that $\mathrm{NH}_{4}{ }^{+}$in wetland inflow was converted to $\mathrm{NO}_{3}{ }^{-}$near the wetland entrance, and then denitrified prior to leaving. The median inflow DO concentration was $5.21 \mathrm{mg} \mathrm{L}^{-1}$ but outflow was reduced to $1.1 \mathrm{mg} \mathrm{L}^{-1}$. It is possible that nitrification of influent $\mathrm{NH}_{4}{ }^{+}$occurred near the wetland inlet, and denitrification of $\mathrm{NO}_{3}{ }^{-}$may have occurred prior to leaving through the outlet, thus lowering both $\mathrm{NH}_{4}{ }^{+}$and $\mathrm{NO}_{3}{ }^{-}$concentrations.

Dry detention basins constructed to reduce runoff receive a nitrogen reduction credit of $10 \%$ based on NC guidelines [22]. During some of the smaller rain events $(<0.3 \mathrm{~cm})$ sampled, there was a $10 \%$ or more TDN treatment efficiency observed for the basin. It is likely that plant uptake and/or denitrification may have been responsible for TDN removal during those small rain events. However, for most storms sampled, the $10 \%$ reduction in TDN was not realized at Jaycee Park. Research has shown that the treatment efficiency of dry basins is highly variable, and many basins export nitrogen [8]. It is likely that the relatively large main outlet pipe $(60 \mathrm{~cm}$ diameter) for the basin was too close in size to the main inlet pipe ( $90 \mathrm{~cm}$ diameter), thus allowing large volumes of inflow to quickly exit. The small residence time of water in the dry basin was insufficient to lower the DO and ORP values for most storms despite relatively high concentrations of DOC (in relation to $\mathrm{NO}_{3}{ }^{-}$). Nitrate reduction via denitrification was not significant in the dry detention basin, because stormwater was not in the basin long enough to stimulate a drop in DO and ORP to allow for denitrification. SCMs in Greenville and most of NC are designed to store and treat runoff produced from a $2.5 \mathrm{~cm}$ rain event. However, runoff entering the basin from that size storm typically passed through the outlet within $5 \mathrm{~h}$. In contrast, the outlet structure for the wetland had much smaller main draw downpipes $(10 \mathrm{~cm}$ and $7.5 \mathrm{~cm}$ diameters) that reduced outflow rates by more than one order of magnitude in comparison to the dry basin. The longer residence times likely facilitated a drop in DO and ORP, decomposition of organic debris, and denitrification.

The wetland reduced TDN concentrations by about $63 \%$, thus exceeding the $44 \%$ nitrogen credit associated with stormwater wetlands in North Carolina [22]. The nitrogen reduction efficiency of the wetland in this research was similar to the $\mathrm{NO}_{3}{ }^{-} \mathrm{N}$ treatment efficiencies reported $(68 \%)$ in a study of a nearby $(\sim 5 \mathrm{~km})$ stormwater wetland [30]. The median TDN treatment efficiency of this wetland also exceeded the median efficiency $(48 \%)$ of 19 wetlands reported in a literature review [8]. Overtime, as the planted wetland trees grow and mature, the nitrogen treatment efficiency of the wetland may increase due to a greater plant uptake of nutrients and water [31], increases in soil carbon, and development of other biogeochemical conditions conducive to denitrification [32]. Prior studies in North Carolina [32] and Sweden [33] comparing the nitrogen treatment efficiency of young and more mature wetlands have shown improvements in treatment with age. However, as the wetland vegetation and trees enlarge in the Jaycee wetland, maintenance intensity may also need to increase due to more organic matter and sediment being deposited into the wetland [11,32]. Partial clogging of the relatively small wetland outlet pipes was noted after several storms. The debris was removed following larger storms, but if routine maintenance is not performed on the wetland, then retention and treatment of stormwater may be negatively impacted [16,32]. Clogged outlets will reduce outflow rates and may trigger more frequent overtopping of the outlet structure and bypass of treatment if consecutive storms occur within a few days of each other. Prior research [32] comparing the treatment efficiency of a stormwater wetland one and six years after construction showed a $16 \%$ decline in peak discharge attenuation due to loss of storage capacity from organic and sediment build up. Routine maintenance of the wetland will be critical to its performance. 


\section{Conclusions}

The goal of this study was to determine if the conversion of a dry detention basin to a stormwater wetland would reduce nitrogen loading to an impaired stream. Outflow from the wetland had significantly lower concentrations of TDN and DIN in comparison to outflow from the dry basin. There was an order of magnitude difference in the retention time of stormwater in the wetland, and significantly lower ORP and DO concentrations that may have facilitated denitrification. Results from this study suggest that conversion of other dry detention basins to wetlands may result in improved water quality. There are 20 other dry detention basins within the Greens Mill Run watershed that may also be good candidates for wetland conversion [24]. Given the popularity of dry detention basins in urban areas of the US [4] and other countries [10,34], there may be other great locations to improve water quality via wetland retrofits.

Author Contributions: C.P.H.J. and G.I. were responsible for each component of the manuscript. Both authors have read and agreed to the published version of the manuscript.

Funding: This research was funded by a contract with Sound Rivers contract number 36621, via a subaward from the NC DEQ 319 Program and NC Clean Water Management Trust Fund.

Acknowledgments: The authors would like to acknowledge project partners at North Carolina State University and Sound Rivers, and student assistants Sam Cary and Alec Fediuk.

Conflicts of Interest: The authors declare no conflict of interest.

\section{References}

1. United States Environmental Protection Agency. Impaired Waters and TMDLs. Available online: https: //www.epa.gov/tmdl/impaired-waters-and-stormwater (accessed on 20 November 2020).

2. Luo, H.; Guan, L.; Jing, Z.; He, B.; Cao, X.; Zhang, Z.; Tao, M. Performance Evaluation of Enhanced Bioretention Systems in Removing Dissolved Nutrients in Stormwater Runoff. Appl. Sci. 2020, 10, 3148. [CrossRef]

3. Hogan, D.M.; Walbridge, M.R. Best Management Practices for Nutrient and Sediment Retention in Urban Stormwater Runoff. J. Environ. Qual. 2007, 36, 386-395. [CrossRef] [PubMed]

4. Blaszczak, J.R.; Steele, M.K.; Badgley, B.D.; Heffernan, J.B.; Hobbie, S.E.; Morse, J.L.; Rivers, E.N.; Hall, S.J.; Neill, C.; Pataki, D.E.; et al. Sediment chemistry of urban stormwater ponds and controls on denitrification. Ecosphere 2018, 9, e02318. [CrossRef]

5. Fronczyk, J.; Mumford, K.A. The Impact of Temperature on the Removal of Inorganic Contaminants Typical of Urban Stormwater. Appl. Sci. 2019, 9, 1273. [CrossRef]

6. Wang, J.; Chen, J.; Jin, Z.; Guo, J.; Yang, H.; Zeng, Y. Simultaneous removal of phosphate and ammonium nitrogen from agricultural runoff by amending soil in lakeside zone of Karst area, Southern China. Agric. Ecosyst. Environ. 2020, 289, 106745. [CrossRef]

7. Conley, D.J.; Paerl, H.W.; Howarth, R.W.; Boesch, D.F.; Seitzinger, S.P.; Havens, K.E.; Lancelot, C.; Likens, G.E. Controlling eutrophication: Nitrogen and phosphorus. Science 2009, 323, 1014-1015. [CrossRef]

8. Collins, K.A.; Lawrence, T.J.; Stander, E.K.; Jontos, R.J.; Kaushal, S.S.; Newcomer, T.A.; Grimm, N.B.; Ekberg, M.L.C. Opportunities and challenges for managing nitrogen in urban stormwater: A review and synthesis. Ecol. Eng. 2010, 36, 1507-1519. [CrossRef]

9. Al-Janabi, A.M.S.; Ghazali, A.H.; Yusuf, B.; Sammen, S.S.; Afan, H.A.; Al-Ansari, N.; Shahid, S.; Yaseen, Z.M. Optimizing Height and Spacing of Check Dam Systems for Better Grassed Channel Infiltration Capacity. Appl. Sci. 2020, 10, 3725. [CrossRef]

10. Shammaa, Y.; Zhu, D.Z.; Gyürék, L.L.; Labatiuk, C.W. Effectiveness of dry ponds for stormwater total suspended solids removal. Can. J. Civ. Eng. 2002, 29, 316-324. [CrossRef]

11. Qualls, R.G.; Heyvaert, A.C. Accretion of Nutrients and Sediment by a Constructed Stormwater Treatment Wetland in the Lake Tahoe Basin. J. Am. Water Resour. Assoc. 2017, 53, 1495-1512. [CrossRef] 
12. Hunt, W.F. Urban Waterways, Urban Stormwater Structural Best Management Practices (BMPs); North Carolina Cooperative Extension Service Publication: Raleigh, NC, USA, 1999.

13. Payne, E.G.I.; Fletcher, T.D.; Cook, P.L.M.; Deletic, A.; Hatt, B.E. Processes and Drivers of Nitrogen Removal in Stormwater Biofiltration. Crit. Rev. Environ. Sci. Technol. 2014, 44, 796-846. [CrossRef]

14. Guerrero, J.; Mahmoud, A.; Alam, T.; Chowdhury, M.A.; Adetayo, A.; Ernest, A.; Jones, K.D. Water Quality Improvement and Pollutant Removal by Two Regional Detention Facilities with Constructed Wetlands in South Texas. Sustainability 2020, 12, 2844. [CrossRef]

15. Lenhart, H.A.; Hunt, W.F.; Burchell, M.R. Harvestable Nitrogen Accumulation for Five Storm Water Wetland Plant Species: Trigger for Storm Water Control Measure Maintenance? J. Environ. Eng. 2012, 972-978. [CrossRef]

16. Blecken, G.T.; Hunt, W.F.; Al-Rubaei, A.M.; Viklander, M.; Lord, W.G. Stormwater control measure (SCM) maintenance considerations to ensure designed functionality. Urban Water J. 2017, 14, 278-290. [CrossRef]

17. Morse, J.R.; McPhillips, L.E.; Shapleigh, J.P.; Walter, M.T. The Role of Denitrification in Stormwater Detention Basin Treatment of Nitrogen. Environ. Sci. Technol. 2017, 7928-7935. [CrossRef]

18. Ranjbar, F.; Jalali, M. Measuring and modeling ammonium adsorption by calcareous soils. Environ. Monit. Assess. 2013, 185, 3191-3199. [CrossRef]

19. Vepraskus, M.J.; Faulkner, S.P. Redox Chemistry of Hydric Soils. In Wetland Soils Genesis, Hydrology, Landscapes, and Classification, 1st ed.; Richardson, J.L., Veprasksus, M.J., Eds.; Lewis Publishers: Boca Raton, FL, USA, 2001; pp. 85-105.

20. Del Rosario, K.L.; Humphrey, C.P.; Mitra, S.; O’Driscoll, M. Nitrogen and Carbon Dynamics beneath on-site wastewater treatment systems in Pitt County, North Carolina. J. Water Sci. Technol. 2014, 69, 663-671. [CrossRef]

21. Havlin, J.L.; Beaton, J.D.; Tisdale, S.L.; Nelson, W.L. Soil Fertility and Fertilizers, 6th ed.; Prentice Hall: Upper Saddle River, NJ, USA, 1999; pp. 86-153.

22. North Carolina Department of Environmental Quality. Nutrient Practices and Crediting. Available online: https:/deq.nc.gov/about/divisions/water-resources/planning/nonpoint-source-management/nutrientoffset-information\#approved-nutrient-reduction-practices (accessed on 15 November 2020).

23. North Carolina Department of Environmental Quality. Tar-Pamlico Nutrient Strategy. Available online: https:/deq.nc.gov/about/divisions/water-resources/planning/nonpoint-source-management/nutrientstrategies/tar-pamlico (accessed on 20 November 2020).

24. Hazen and Sawyer. City of Greenville Greens Mill Run Watershed Master Plan. Available online: http: //www.greenvillenc.gov/home/showdocument?id=13142 (accessed on 24 November 2020).

25. North Carolina Department of Environmental Quality, Stormwater Calculations. Available online: https://files.nc.gov/ncdeq/Energy\%20Mineral\%20and\%20Land\%20Resources/Stormwater/BMP\% 20Manual/B\%20\%20Stormwater\%20Calculations.pdf (accessed on 24 November 2020).

26. USGS National Water Information System: Web Interface. USGS 02084000 Tar River at Greenville, NC. Available online: https://waterdata.usgs.gov/nwis/uv?site_no=02084000 (accessed on 15 November 2020).

27. Humphrey, C.P.; Jernigan, J.; Iverson, G.; Serozi, B.; O’Driscoll, M.; Pradhan, S.; Bean, E. Field Evaluation of Nitrogen Treatment by Conventional and Single-Pass Sand Filter Onsite Wastewater Systems in the North Carolina Piedmont. Water Air Soil Pollut. 2016, 227, 255. [CrossRef]

28. Mitsch, W.J.; Gosselink, J.G. Wetlands, 3rd ed.; John Wiley \& Sons, Inc.: New York, NY, USA, 2000; pp. $155-204$.

29. Robertson, W.D.; Cherry, W. In Situ Denitrification of Septic-System Nitrate Using Reactive Porous Media Barriers: Field Trials. Groundwater 1995, 33, 99-111. [CrossRef]

30. Humphrey, C.; Chaplinski, N.; O’Driscoll, M.; Kelley, T.; Richards, S. Nutrient and Escherichia coli Attenuation in a Constructed Stormwater Wetland in the North Carolina Coastal Plain. Environ. Nat. Resour. Res. 2014, 4, 12-22. [CrossRef]

31. Wullschleger, S.D.; Meinzer, F.C.; Vertessy, R.A. A review of whole-plant water use studies in trees. Tree Physiol. 1998, 18, 499-512. [CrossRef]

32. Merriman, L.S.; Hunt, W.F. Maintenance versus Maturation: Constructed Storm-Water Wetland's Fifth-Year Water Quality and Hydrologic Assessment. J. Environ. Eng. 2014. [CrossRef] 
33. Al-Rubaei, A.M.; Engstrom, M.; Viklander, M.; Blecken, G. Long-tern hydraulic and treatment performance of a 19-year old constructed stormwater wetland- Finally matured or in need of maintenance? Ecol. Eng. 2016, 95, 73-82. [CrossRef]

34. Carpenter, J.F.; Vallet, B.; Pelletier, G.; Lessard, P.; Vanrolleghem, P.A. Pollutant removal efficiency of a retrofitted stormwater detention pond. Water Qual. Res. J. Can. 2014, 49, 124-134. [CrossRef]

Publisher's Note: MDPI stays neutral with regard to jurisdictional claims in published maps and institutional affiliations.

(C) 2020 by the authors. Licensee MDPI, Basel, Switzerland. This article is an open access article distributed under the terms and conditions of the Creative Commons Attribution (CC BY) license (http://creativecommons.org/licenses/by/4.0/). 